Robert J. Barro is a professor of economics at Harvard University. The initial version of this paper was written while he was Houblon-Norman research fellow at the Bank of England. This research was supported by the National Science Foundation.

\section{Inflation and Growth}

\section{Robert J. Barro}

$\mathrm{n}$ recent years, many central banks have placed increased emphasis on price stability. Monetary policy- whether expressed in terms of interest rates or growth of monetary aggregates- has been increasingly geared toward the achievement of low and stable inflation. Central bankers and most other observers view price stability as a worthy objective because they think that inflation is costly. Some of these costs involve the average rate of inflation, and others relate to the variability and uncertainty of inflation. But the general idea is that businesses and households are thought to perform poorly when inflation is high and unpredictable.

The academic literature contains a lot of theoretical work on the costs of inflation, as reviewed recently by Briault (1995). This analysis provides a presumption that inflation is a bad idea, but the case is not decisive without supporting empirical findings. Although some empirical results (also surveyed by Briault) suggest that inflation is harmful, the evidence is not overwhelming. It is therefore important to carry out additional empirical research on the relation between inflation and economic performance. This article explores this relation in a large sample of countries over the last 30 years.

\section{DATA}

The data set covers over 100 countries from 1960 to 1990. Table 1 provides information about the behavior of inflation in this sample. Annual inflation rates were computed in most cases from consumer price indexes. (The deflator for the gross domestic product was used in a few in-

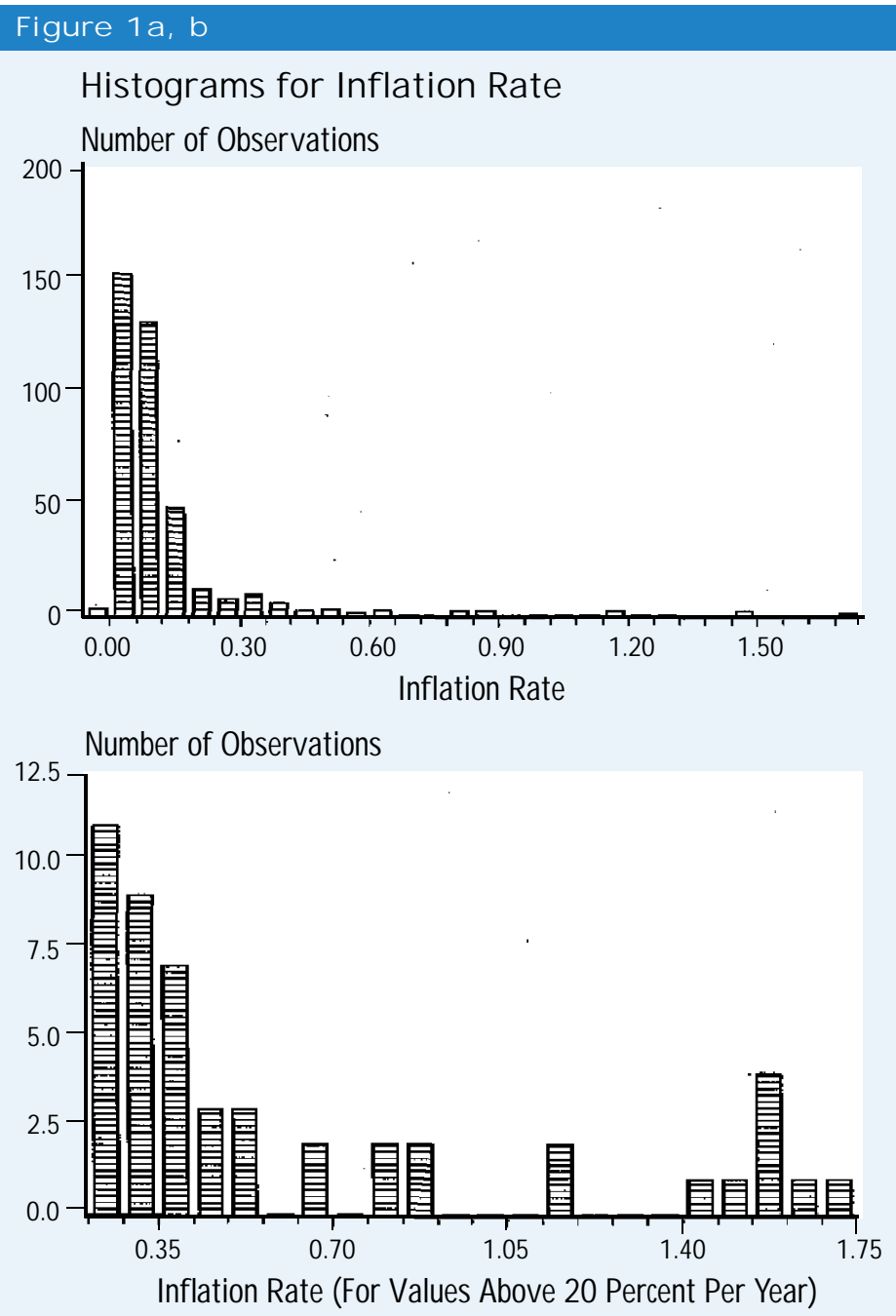

stances, when the data on consumer prices were unavailable.) Table 1 shows the mean and median across the countries of the inflation rates in three decades: 1960-70, 1970-80, and 1980-90. The median inflation rate was 3.3 percent per year in the 1960s (117 countries), 10.1 percent in the 1970s (122 countries), and 8.9 percent in the 1980s (119 countries). The upper panel of Figure 1 provides a histogram for the inflation rates observed over the three decades. The bottom panel applies to the 44 observations for which the inflation rate exceeded 20 percent per year. ${ }^{1}$
1 Table 1 shows that the crosscountry mean of inflation exceeded the median for each decade. This property reflects the skewing of inflation rates to the right, as shown in Figure 1. That is, there are a number of outliers with positive inflation rates of large magnitude, but none with negative inflation rates of high magnitude. Because this skewness increased in the 1980s, the mean inflation rate rose from the 1970 s to the 1980 s, although the median rate declined. 
Table 1

Descriptive Statistics on Inflation, Growth, and Investment*

\begin{tabular}{|c|c|c|c|}
\hline Variable & Mean & Median & Number of Countries \\
\hline \multicolumn{4}{|l|}{$1960-70$} \\
\hline Inflation rate & .054 & .033 & 117 \\
\hline Standard deviation of inflation rate & .039 & .024 & 117 \\
\hline Grow th rate of real per capita GDP & .028 & .031 & 118 \\
\hline Ratio of investment to GDP & .168 & .156 & 119 \\
\hline \multicolumn{4}{|l|}{$1970-80$} \\
\hline Inflation rate & .133 & .101 & 122 \\
\hline Standard deviation of inflation rate & .075 & .054 & 122 \\
\hline Grow th rate of real per capita GDP & .023 & .025 & 123 \\
\hline Ratio of investment to GDP & .191 & .193 & 123 \\
\hline \multicolumn{4}{|l|}{ 1980- 90} \\
\hline Inflation rate & .191 & .089 & 119 \\
\hline Standard deviation of inflation rate & .134 & .049 & 119 \\
\hline Growth rate of real per capita GDP & .003 & .004 & 121 \\
\hline Ratio of investment to GDP & .174 & .173 & 128 \\
\hline \multicolumn{4}{|c|}{$\begin{array}{l}\text { The inflation rate is computed on an annual basis for each country from data on consumer price indexes (from the World Bank; STARS databank; issues of World Tables; } \\
\text { International Monetary Fund; International Financial Statistics- yearbook issues; and individual country sources). In a few cases, figures on the GDP deflater were used. } \\
\text { The average inflation rate for each country in each decade is the mean of the annual rates. The standard deviation for each country in each decade is the square root of the } \\
\text { average squared difference of the annual inflation rate from the decadal mean. The values shown for inflation in this table are the mean or median across the countries of } \\
\text { the decade-average inflation rates. Similarly, the figures for standard deviations are the mean or median across the countries of the standard deviations for each decade. } \\
\text { The growth rates of real per capita GDP are based on the purchasing power- adjusted GDP values compiled by Summers and Heston (1993). For the } 1985-90 \text { period, some } \\
\text { of the figures come from the World Bank (and are based on market exchange rates rather than purchasing-power comparisons). The ratios of real investment (private plus } \\
\text { public) to real GDP come from Summers and Heston (1993). These values are averages for 1960-69, 1970-79, and 1980-89. }\end{array}$} \\
\hline
\end{tabular}

The annual data were used for each country over each decade to compute a measure of inflation variability, the standard deviation of the inflation rate around its decadal mean. Table 1 shows the mean and median of these standard deviations for the three decades. The median was 2.4 percent per year in the 1960s, 5.4 percent in the 1970s, and 4.9 percent in the 1980s. Thus, a rise in inflation variability accompanied the increase in the average inflation rate since the 1960 s.

Figure 2 confirms the well-known view that a higher variability of inflation tends to accompany a higher average rate of inflation. ${ }^{2}$ These charts providescatter plots of the standard deviation of inflation (mea-

2 See, for example, Okun (1971) and Logue and Willett (1976). sured for each country around its own decadal mean) against the average inflation rate (the mean of each country's inflation rate over the decade). The upper panel considers only inflation rates below 15 percent per year, the middle panel includes values above 15 percent per year, and thelower panel covers the entire range. The positive, but imperfect, relation between variability and mean is apparent throughout.

Table 1 also gives the means and medians of the growth rate of real per capita gross domestic product (GDP) and the ratio of investment to GDP for the three decades. The median growth rate fell from 3.1 percent in the 1960 s ( 118 countries) to 2.5 percent in the 1970 s ( 123 countries) and 0.4 percent in the 1980s (121 countries). The median investment ratio went from 16 percent in the 1960s to 19 percent in the 1970s and 17 percent in the 1980s. In contrast to inflation rates, the growth rates and investment ratios tend to 
be symmetrically distributed around the median.

\section{FRAMEWORK FOR THE ANALYSIS OF GROWTH}

To assess the effect of inflation on economic growth, I use a system of regression equations in which many other determinants of growth are held constant. The framework is based on an extended view of the neoclassical growth model, as described in Barro and Sala-i-Martin (1995, Chapters 1 and 2). My empirical implementations of this approach include Barro (1991 and 1996).

A general notion in the framework is that an array of government policies and private-sector choices determine where an economy will go in thelong run. For example, favorable public policies-including better maintenance of the rule of law and property rights, fewer distortions of private markets, less non productive government consumption, and greater public investment in high-return areas- lead in the long run to higher levels of real per capita GDP. (Henceforth, the term GDP will be used as a shorthand to denote real per capitaGDP.) Similarly, a greater willingness of theprivate sector to save and a reduced tendency to expend resources on child rearing (lower fertility and population growth) tend to raise standards of living in the long run.

Given the determinants of the longrun position, an economy tends currently to grow faster the lower its GDP. In other words, an economy's per capita growth rate is increasing in the gap between its longterm prospective GDP and its current GDP. This force generates a convergence tendency in which poor countries grow faster than rich countries and tend thereby to catch up in a proportional sense to therich places. However, poor countries grow fast only if they have favorable settings for government policies and private-sector choices. If a poor country selects unfavorable policies- a choice that likely explains why the country is currently observed to be poorthen its growth rate will not be high and it will not tend to catch up to the richer places.

\section{Figure 2a, b, c}

\section{Standard Deviation of Inflation} Versus Mean Inflation
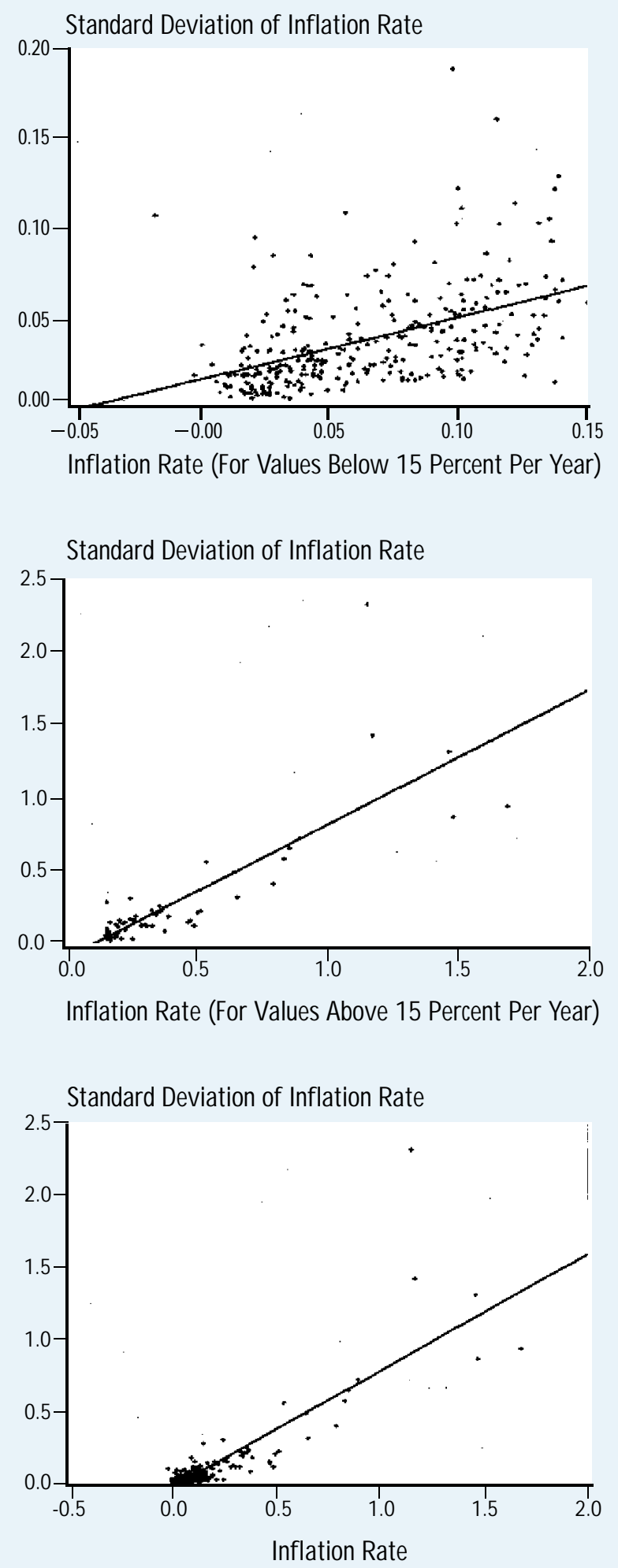
Table 2

Regressions for Per Capita Growth Rate*

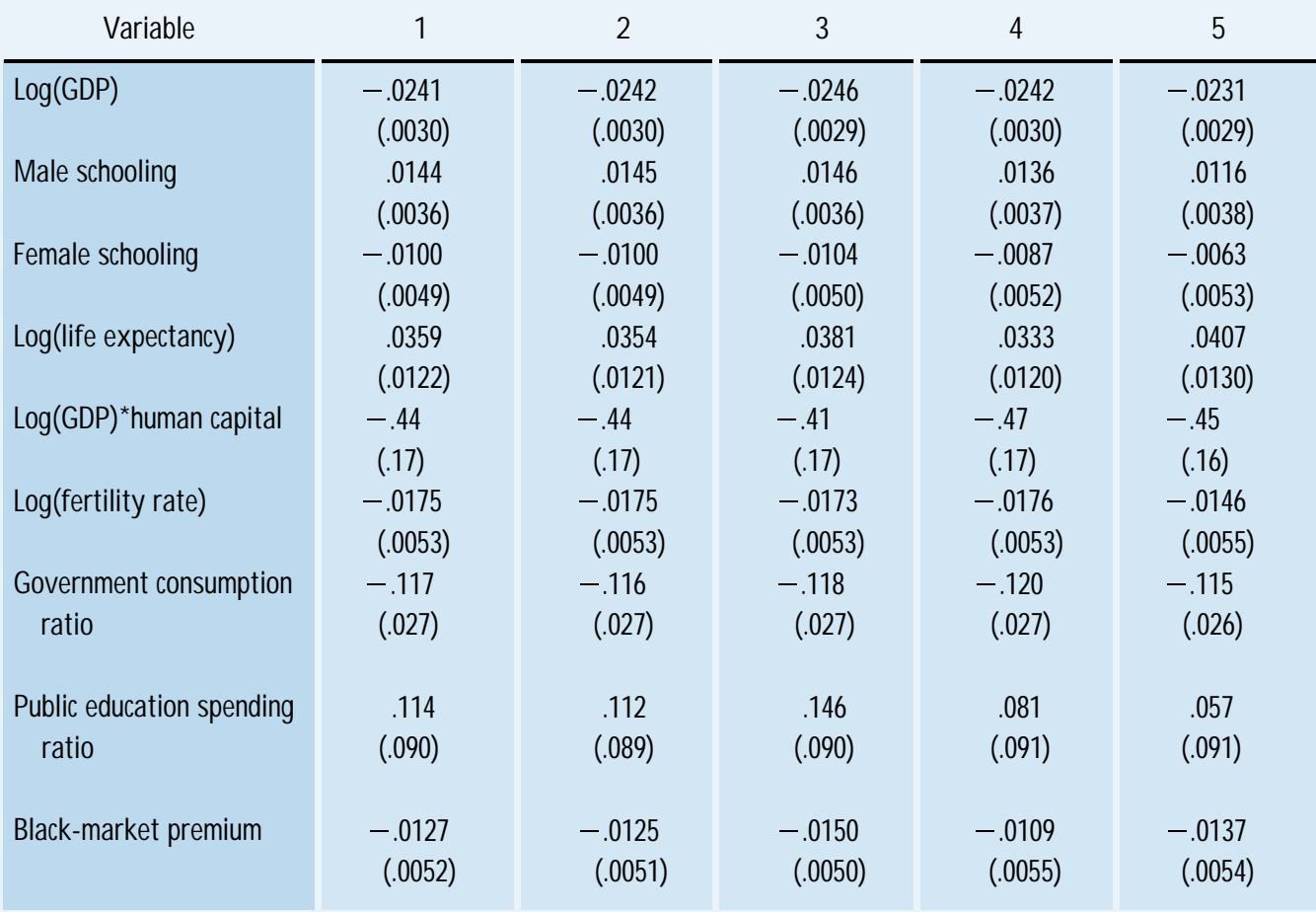

* Standard errors of the coefficient estimates are shown in parentheses. The $R^{2}$ values and numbers of observations apply to each period individually.

The systems have three equations, where the dependent variables are the growth rate of real per capita GDP for 1965-75, 1975-85, and 1985- 90. The variables GDP (real per capita GDP) and schooling (years of attainment at the secondary and higher levels) refer to 1965, 1975, and 1985. Life expectancy at birth is for 1960- 64, 1970- 74, and 1980-84. The rule-of-law index applies to the early 1980s (one observation for each country). The terms-of-trade variable is the growth rate over each period of the ratio of export to import prices. The variable $\log ($ GDP)*human capital is the product of $\log ($ GDP) (expressed as a deviation from the sample mean) and the estimated effect of the schooling and life-expectancy variables (also expressed as deviations from sample means). Variables measured as averages over each period are the log of the total fertility rate, the ratio of government consumption (exclusive of defense and education) to GDP, the ratio of public educational spending to GDP, the black-market premium on foreign exchange, the ratio of gross investment (public plus private) to GDP, the Gastil/ Bollen indexes of political rights (where 0 indicates the fewest rights and 1 the most), and the CPI inflation rate. The standard deviation of the inflation rate is measured from annual observations in relation to the mean inflation rate for each period. The Latin American dummy equals 1 for countries in Latin America and 0 otherwise. Individual constants (not shown) are estimated for each period.

(continued on following page)

Another important element is a country's human capital in the forms of education and health. For given values of prospective and actual GDP, a country grows faster-that is, approaches its longrun position more rapidly- the greater its current level of human capital. This effect arises because, first, physical capital tends to expand rapidly to match a high endowment of human capital, and, second, a country with more human capital is better equipped to acquire and adapt the efficient technologies that have been developed in the leading countries.

\section{PANEL ESTIMATES OF GROWTH EQUATIONS}

\section{0 verview of the Results}

Table 2 lists the explanatory variables used as determinants of the growth rate of real per capita GDP. The details for a similar setup are in Barro (1996). The results apply to growth rates and the other variables observed for 78 countries from 1965 to 1975,89 countries for 1975 to 1985 , and 84 countries from 1985 to 1990 . This sample reflects the availability of the necessary data. The first period starts in 1965, 
Table 2

\section{Regressions for Per Capita Growth Rate*}

\begin{tabular}{|c|c|c|c|c|c|}
\hline Variable & 1 & 2 & 3 & 4 & 5 \\
\hline Rule-of-law index & $\begin{array}{c}.00426 \\
(.00093)\end{array}$ & $\begin{array}{l}.00424 \\
(.00093)\end{array}$ & $\begin{array}{l}.00426 \\
(.00093)\end{array}$ & $\begin{array}{l}.00418 \\
(.00095)\end{array}$ & $\begin{array}{c}.00404 \\
(.00093)\end{array}$ \\
\hline Terms-of-trade change & $\begin{array}{l}.126 \\
(.028)\end{array}$ & $\begin{array}{l}.127 \\
(.028)\end{array}$ & $\begin{array}{l}.129 \\
(.028)\end{array}$ & $\begin{array}{c}.123 \\
(.028)\end{array}$ & $\begin{array}{l}.117 \\
(.028)\end{array}$ \\
\hline Investment ratio & $\begin{array}{l}.019 \\
(.022)\end{array}$ & $\begin{array}{l}.020 \\
(.022)\end{array}$ & $\begin{array}{l}.018 \\
(.022)\end{array}$ & $\begin{array}{l}.024 \\
(.022)\end{array}$ & $\begin{array}{l}.013 \\
(.022)\end{array}$ \\
\hline Democracy index & $\begin{array}{c}.063 \\
(.025)\end{array}$ & $\begin{array}{l}.063 \\
(.025)\end{array}$ & $\begin{array}{l}.066 \\
(.025)\end{array}$ & $\begin{array}{l}.059 \\
(.026)\end{array}$ & $\begin{array}{l}.066 \\
(.026)\end{array}$ \\
\hline Democracy index squared & $\begin{array}{r}-.064 \\
(.022)\end{array}$ & $\begin{array}{r}-.063 \\
(.022)\end{array}$ & $\begin{array}{r}-.067 \\
(.023)\end{array}$ & $\begin{array}{r}-.060 \\
(.023)\end{array}$ & $\begin{array}{r}-.066 \\
(.023)\end{array}$ \\
\hline Inflation rate & $\begin{array}{r}-.0236 \\
(.0048)\end{array}$ & $\begin{array}{r}-.0209 \\
(.0082)\end{array}$ & $\begin{array}{r}-.0197 \\
(.0069)\end{array}$ & $\begin{array}{r}-.0306 \\
(.0083)\end{array}$ & $\begin{array}{r}-.0254 \\
(.0086)\end{array}$ \\
\hline $\begin{array}{l}\text { Standard deviation of } \\
\text { inflation rate }\end{array}$ & - & $\begin{array}{r}-.0036 \\
(.0086)\end{array}$ & - & - & - \\
\hline Latin America dummy & - & - & - & - & $\begin{array}{r}-.0060 \\
(.0034)\end{array}$ \\
\hline $\mathbf{R}^{2}$ & $.63, .60, .48$ & $.63, .60, .49$ & $.64, .60, .46$ & $.63, .59, .48$ & $.63, .61, .49$ \\
\hline Number of observations & $78,89,84$ & $78,89,84$ & $78,89,84$ & $78,89,84$ & $78,89,84$ \\
\hline $\begin{array}{l}\text { Estimation is by instrumental variables } \\
\text { Column } 3 \text { uses the five-year earlier va } \\
\text { as an instrument. The other instrumen } \\
\text { expectancy, rule-of-law, and terms-of-t } \\
\text { premium and the govenrment-spendin } \\
\text { errors. The estimated correlation of the } \\
\text { and } 0.07 \text { between the } 1975-85 \text { and } 1 \\
\text { independent over the time periods. }\end{array}$ & $\begin{array}{l}\text { Imns } 1 \text { and } 2 \text { indu } \\
\text { of infl ation as instr } \\
\text { all columns are th } \\
\text { variables; and ear } \\
\text { investment ratios } \\
\text { is for column } 1 \text { is } \\
90 \text { equations. The }\end{array}$ & $\begin{array}{l}\text { inflation as an inst } \\
\text { olumns } 4 \text { and } 5 \text { us } \\
\text { r earlier value of I } \\
\text { of the other varia } \\
64 \text {. The estimatic } \\
\text { tween the } 1965- \\
\text { similar for the ot }\end{array}$ & $\begin{array}{l}\text { Column } 2 \text { also use } \\
\text { olonial status as in } \\
\text { (for example, for } \\
\text { example, the } 196 \\
\text { for different error } \\
975-85 \text { equations } \\
\text { ins. The estimates }\end{array}$ & $\begin{array}{l}\text { ddard deviation of in } \\
\text { s. Column } 5 \text { also use } \\
\text { the } 1965-75 \text { equat } \\
\text { fuation uses the ave } \\
\text { as in each period and } \\
\text { etween the } 1965-7 \text { ? } \\
\text { ally the same if the }\end{array}$ & $\begin{array}{l}\text { as an instrument. } \\
\text { atin America dummy } \\
\text { e schooling, life- } \\
\text { f the black-market } \\
\text { rrelatiuon across these } \\
985 \text { - } 90 \text { equations, } \\
\text { re assumed to be }\end{array}$ \\
\hline
\end{tabular}

rather than 1960, so that five-year lags of the explanatory variables are available.

The estimation is by instrumental variables, where the instruments consist mainly of prior values of the regressors. For example, the 1965-75 equation includes the log of 1965 GDP on the righthand side and uses the log of 1960 GDP as an instrument. This procedure should lessen the estimation problems caused by temporary measurement error in GDP. The right-hand side also contains period averages of several variables-government spending ratios, fertility rates, blackmarket premia, and investment ratiosand uses five-year earlier values of these variables as instruments.
The use of lagged variables as instruments is problematic, although better alternatives are not obvious. One favorable element here is that the residuals from the growth equations turn out to be virtually uncorrelated over the time periods. In most respects, the instrumental results do not differ greatly from OLS estimates. The largest difference turns out to be for the estimated effect of the investment ratio on the growth rate.

Since the general pattern of results has been considered elsewhere, ${ }^{3} \mid$ will provide only a brief sketch here and will focus the main discussion on the effects of inflation. One familiar finding in Table 2 is that the estimated coefficient on initial $\log (G D P)$ is
3 See, for example, Barro (1996). 
significantly negative with a magnitude of around 2.5 percent. Thus, conditional on the other variables, convergence in real per capita GDP occurs at roughly 2.5 percent per year. ${ }^{4}$ Growth tends also to be increasing in the initial levels of human capital in the forms of education (average years of school attainment at the secondary and higher levels) and health (proxied by the log of life expectancy at birth). The negative coefficient on the interaction term between initial GDP and human capital ${ }^{5}$ means that the rate of convergence is higher in a place that starts with more human capital.

For given starting values of the state variables (represented by initial human capital and GDP), growth is estimated to fall with higher fertility (the average woman's total fertility rate), higher government consumption (the ratio to GDP of government consumption, exclusive of spending on education and defense), and a larger black-market premium on foreign exchange (intended as a proxy for market distortions more broadly).

Growth is enhanced by greater maintenance of the rule of law, as measured by Knack and Keefer's (1995) subjective index. One problem here is that this variable is observed only in the early 1980s (and is included among the instruments). Growth also rises in response to a contemporaneous improvement in the terms of trade, measured by the growth rate of the ratio of export prices to import prices. (The contemporaneous terms-of-trade change is included with the instruments.)

The estimated coefficients on the ratio of public educational spending to GDP and on the ratio of total real investment to real GDP are positive, but insignificant. The estimated coefficient on investment becomes higher and significant if the contemporaneous investment ratio is included with the instruments. (The timing in the data indicates that much of the positive association between investment and growth represents the reverse response of investment to growth.) The estimate becomes even larger and resembles that reported in other studies, such as Mankiw, Romer, and
Weil (1992), if life expectancy is deleted as a regressor.

Finally, an increase in democracymeasured by indexes of political rights from Gastil (1982-83) and Bollen (1990)- have a nonlinear effect (which I did not find for log[GDP] or the humancapital variables). At low levels of democracy, more freedom is estimated to raise growth. But once a moderate level of democracy is attained (corresponding roughly to "half" the way toward full representative democracy), further liberalization is estimated to reduce growth. These effects are discussed at length in Barro (1996).

\section{Preliminary Results on Inflation}

To get a first-pass estimate of the effect of inflation on economic growth, I included the inflation rate over each period as an explanatory variable along with the other growth determinants listed in Table 2. If contemporaneous inflation is also included with the instruments, then column 1 of Table 2 indicates that the estimated coefficient of inflation is -0.024 (s.e. $=0.005$ ). Thus, an increase by 10 percentage points in the annual inflation rate is associated on impact with a decline by 0.24 percentage points in the annual growth rate of GDP. Since the "t-statistic" for the estimated coefficient is 4.9 , this result is statistically significant. 6

Figure 3 depicts graphically the relation between growth and inflation. The horizontal axis plots the inflation rate; each observation corresponds to the aver age rate for a particular country over one of the time periods considered (1965-75, 1975-85, and 1985-90). The top panel in the chart considers inflation rates below 15 percent per year, the middle panel includes values above 20 percent per year, and the bottom panel covers the full range of inflation. The vertical axis plots the growth rate of GDP, net of the part of the growth rate that is explained by all of the ex planatory variables aside from the inflation rate. ${ }^{7}$ Thus, the panels illustrate the relation between growth and inflation after all 
of the other growth determinants have been held constant.

The panels of Figure 3 show downwardsloping regression lines (least-squares lines) through thescatter plots. Theslope of the linein the lower panel corresponds approximately to the significantly negative coefficient shown in column 1 of Table 2. The panels show, however, that thefit is dominated by the inverse relation between growth and inflation at high rates of inflation. For inflation rates below 20 percent per year, as shown in the upper panel, the relation between growth and inflation is not statistically significant.

To put it another way, one can reestimate the panel while restricting the observations to those for which the inflation rate is less than some cutoff value, $x$. To get a statistically significant estimate for the inflation coefficient, $x$ has to be raised to roughly 50 percent per year. With an inflation cutoff of 50 percent, the estimated coefficient is $-0.029(0.015)$. For lower values of the cutoff, the estimated coefficient tends to be negative but insignificant; some results are $x=40$ percent, coefficient $=-0.023(0.018) ; x=25$ percent, coefficient $=-0.011(0.027) ; x=15$ percent, coefficient $=-0.032(0.042)$.

The results indicate that there is not enough information in the low-inflation experiences to isolate precisely the effect of inflation on growth, but do not necessarily mean that this effect is small at low rates of inflation. To check for linearity of the relation between growth and inflation, I reestimated the system on the whole sample with separate coefficients for inflation in three ranges: up to 15 percent, between 15 percent and 40 percent, and over 40 percent. The estimated coefficients on inflation in this form are $-0.016(0.035)$ in the low range, $-0.037(0.017)$ in the middle range, and $-0.023(0.005)$ in the upper range. Thus, the clear evidence for the negative relation between growth and inflation comes from the middle and upper intervals. However, since the three estimated coefficients do not differ significantly from each other ( $p$-value $=0.65$ ), the data are consistent with a linear rela-

\section{Figure 3 a, b, c}

\section{Growth Rate Vs. Inflation Rate}
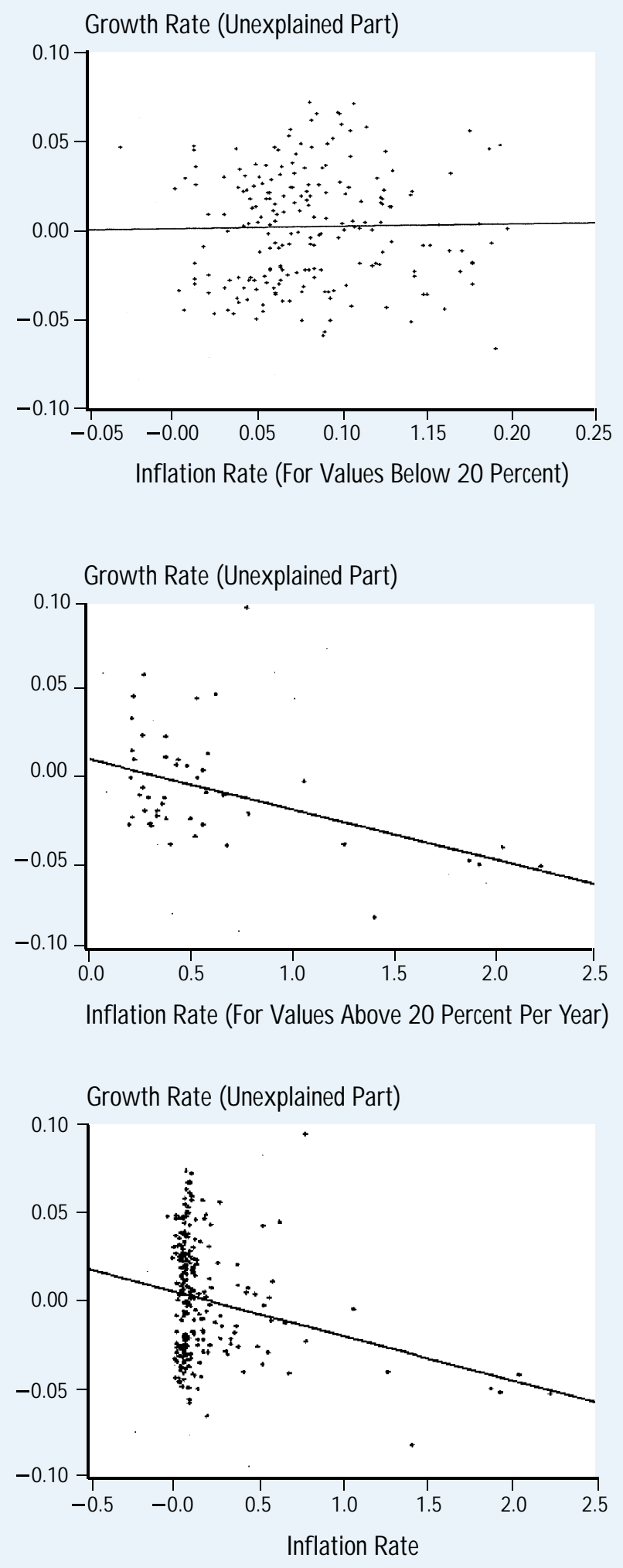


\section{Table 3}

\section{High-Inflation Observations- Period-Average Inflation Rate Exceeds 40 Percent Per Year}

\begin{tabular}{|c|c|c|}
\hline & Country & Inflation Rate \\
\hline \multirow[t]{3}{*}{$1965-75$} & Chile & 0.68 \\
\hline & Indonesia & 0.53 \\
\hline & Uruguay & 0.50 \\
\hline \multirow[t]{10}{*}{$1975-85$} & & \\
\hline & Argentina & 1.26 \\
\hline & Bolivia & 1.06 \\
\hline & Brazil & 0.66 \\
\hline & Haiti & 0.48 \\
\hline & Israel & 0.78 \\
\hline & Peru & 0.56 \\
\hline & Uganda & 0.53 \\
\hline & Uruguay & 0.41 \\
\hline & Zaire & 0.44 \\
\hline \multirow[t]{16}{*}{$1985-90$} & & \\
\hline & Argentina & 1.92 \\
\hline & Brazil & 2.04 \\
\hline & Guinea-Bissau* & 0.53 \\
\hline & Mexico & 0.53 \\
\hline & Mozambique* & 0.48 \\
\hline & Nicaragua & 1.87 \\
\hline & Peru & 2.22 \\
\hline & Poland* & 0.81 \\
\hline & Sierra Leone & 0.63 \\
\hline & Turkey & 0.43 \\
\hline & Uganda & 0.78 \\
\hline & Uruguay & 0.58 \\
\hline & Yugoslavia & 1.41 \\
\hline & Zaire & 0.59 \\
\hline & Zambia & 0.56 \\
\hline
\end{tabular}

${ }^{8}$ This system includes on the right-hand side standard deviations of inflation measured for the periods 1965-75, 1975-85, and 1985- 90 . These variables are also included with the instruments. tionship. In particular, even at low rates of inflation, the data would not reject the hypothesis that growth is negatively related to inflation.

Although statistically significant effects arise only when the high-inflation experi- ences are included, the results are not sensitive to a few outlier observations. Table 3 shows the 27 cases of inflation in excess of 40 percent per year for one of the time periods (1965-75, 1975-85, and 1985-90). Note that U ruguay appears three times (although it is by no means the overall champion for high inflation), and Argentina, Brazil, Peru, Uganda, and Zaire show up twice each. The other countries, with one observation each, are Chile, Indonesia, BoIivia, Haiti, Israel, Guinea-Bissau, M exico, Mozambique, Nicaragua, Poland, Sierra Leone, Turkey, Yugoslavia, and Zambia. (Guinea-Bissau, Mozambique, and Poland are excluded from the regression sample because of missing data on other variables.) The exclusion of any small number of these high-inflation observations$\mathrm{Nicaragua}$ and Zaire had been suggested to me- has a negligible effect on the results.

The estimates are also reasonably stable over time. If different coefficients for inflation are allowed for each period, but the system is otherwise the same as in column 1 of Table 2 , then the resulting estimates are $-0.019(0.015)$ for $1965-75$, $-0.029(0.010)$ for $1975-85$, and -0.023 (0.005) for 1985-90. These values do not differ significantly from each other ( $p$-value $=0.20)$. (The higher significance of the estimated coefficients in the two later periods reflects the larger number of high-inflation observations.)

The standard deviation of inflation can be added to the system to see whether inflation variability has a relation with growth when the average inflation rate is held constant. The strong positive correlation between the mean and variability of inflation (Figure 2) suggests that it would be difficult to distinguish the influences of these two aspects of inflation. However, when the two variables are entered jointly into the regression system in column 2 of Table 2 , the estimated coefficient on inflation remains similar to that found before $(-0.021[0.008])$, and the estimated coefficient on the standard deviation of inflation is virtually zero $\left(-0.004\right.$ [0.009]). ${ }^{8}$ Thus, for a given average rate of inflation, the variability of 
inflation has no significant relation with growth. One possible interpretation of this result is that the realized variability of inflation over each period does not adequately measure the uncertainty of inflation, the variable that one would have expected to be negatively related to growth. This issue is worth further investigation.

\section{The Endogeneity of Inflation}

A key problem in the interpretation of the results is that they need not reflect causation from inflation to growth. Inflation is an endogenous variable, which may respond to growth or to other variables that are related to growth. For example, an inverse relation between growth and inflation would arise if an exogenous slowing of the growth rate tended to generate higher inflation. This increase in inflation could result if monetary authorities re acted to economic slowdowns with expansionary policies. Moreover, if the path of monetary aggregates did not change, then the equality between money supply and demand at each point in time implies that a reduction in the growth rate of output would tend automatically to raise the inflation rate.

N arayana Kocherlakota's commentary uses a sophisticated cash-in-advance theory to focus on this last source of endogeneity bias. To fix ideas, suppose as he does that the money growth rate, $\mu_{t}$, is determined exogenously. The relation be tween the inflation rate, $\pi_{t}$, and $\mu_{\mathrm{t}}$ is given from the money-supply-equals-moneydemand condition by

$$
\pi_{i}=\mu_{i}-g_{i}+v_{n}
$$

where $g_{t}$ is the growth rate of output and $v_{t}$ is an independent shock to velocity (which Kocherlakota takes to be nil). Suppose that the effect of inflation on the growth rate is described by

(2) $g_{p}=-\alpha,+\varepsilon_{p}$

where $e_{t}$ is an independent shock and $\alpha$ is the coefficient that we want to estimate.

\section{Figure 4}

Inflation and Central Bank Independence

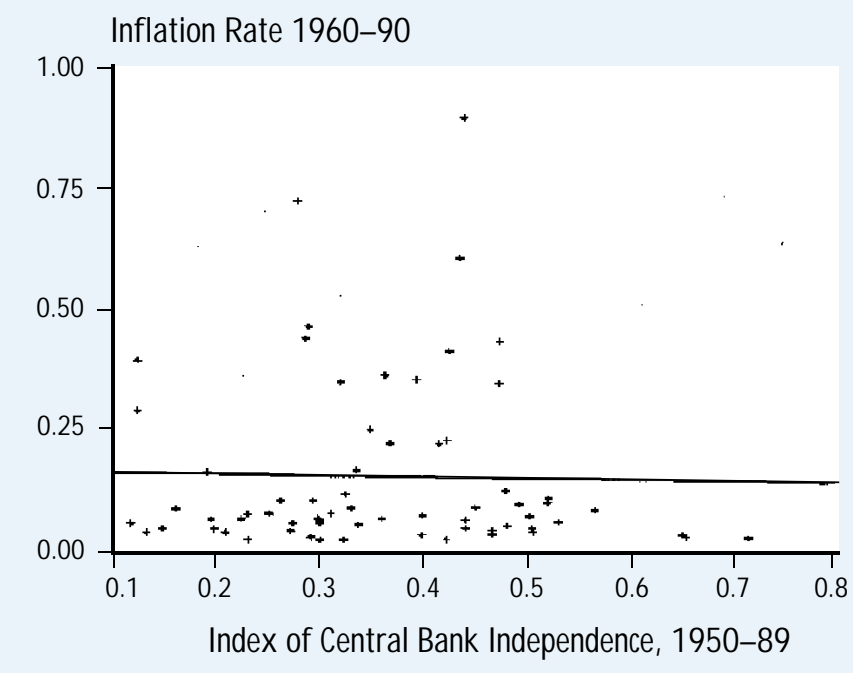

In this framework, the OLS regression coefficient, $\beta$, of $g_{t}$ on, $\pi_{t}$ can be shown to be given by

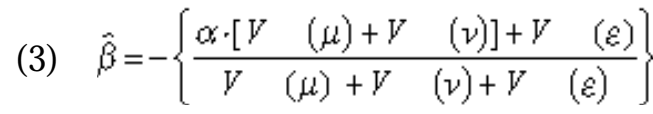

Thus, $\hat{\beta}$ will be close to $\alpha$ if the variances of the shocks to money growth and velocity are much greater than those to output growth.

Kocherlakota uses data from my macroeconomics textbook, normally an impeccable source, to estimate the variances. However, these figures are inappropriate for my panel estimation, which applies to different time periods. Using averages over the three periods in the panel and measuring money by either $\mathrm{M} 1$ or $\mathrm{M} 2$, I find that $\operatorname{VAR}(\mu) \approx .032, \operatorname{VAR}(v) \approx .004$, and $\operatorname{VAR}(\mathrm{e}) \approx .0002$. Then a value $\alpha=0$ corresponds to $\hat{\beta} \approx-.006$, and a value $\alpha=-.020$ corresponds to $\hat{\beta} \approx-.026$. That is, the bias would be small and could not account for the empirical findings. M oreover, if inflation, rather than money growth, were determined exogenously, then the bias would be nil.

The Kocherlakota argument also implies that the results would be very differ- 
ent if one included money growth, rather than inflation, in the growth regressions. If the panel estimation from column 1 of Table 2 is redone with $M 1$ growth replacing the inflation rate, then the estimated coefficient is $-0.0225(0.0057)$. If M 2 growth is used instead, the result is -0.0191

(0.0054). Thus, the estimated coefficient is about the same with money growth as with inflation. Basically, the results reveal an inverse relation between the growth rate of GDP and the growth rate of pricesor money. The distinction between inflation and money growth has nothing to do with the findings.

It is also possible that the endogeneity of inflation would produce a positive relation between inflation and growth. This pattern tends to emerge if output fluctuations are driven primarily by shocks to money or to the aggregate demand for goods.

Another possibility is that some omitted third variable is correlated with growth and inflation. For example, better enforce ment of property rights is likely to spur investment and growth and is also likely to accompany a rules-based setup in which the monetary authority generates a lower average rate of inflation. The idea is that a committed monetary policy represents the application of the rule of law to the behavior of the monetary authority. Some of the explanatory variables in the system attempt to capture the degree of maintenance of the rule of law. However, to the extent that these measures are imperfect, the inflation rate may proxy inversely for the rule of law and thereby show up as a negative influence on growth. The estimated coefficient on the inflation rate could therefore reflect an effect on growth that has nothing to do with inflation per se.

Some researchers like to handle this type of problem by using some variant of fixed-effects estimation; that is, by allowing for an individual constant for each country. This procedure basically eliminates cross-sectional information from the sample and therefore relies on effects within countries from changes over time in inflation and other variables. It is not apparent that problems of correlation of inflation with omitted variables would be less serious in this time-series context than in cross-sections. (If a country is undergoing an inflation crisis or implementing a monetary reform, then it is likely to be experiencing other crises or reforms at the same time.) Moreover, the problems with measurement error and timing of relationships would be more substantial in the time series. The one thing that is clear is that fixed-effects procedures eliminate $a$ lot of information.

Another way to proceed is to find satisfactory instrumental variablesreasonably exogenous variables that are themselves significantly related to inflation. My search along these lines proceeded al ong the sequence now described.

Central bank independence. One promising source of instruments for inflation involves legal provisions that more or less guarantee central bank independence. Recent literature argues that a greater degree of independence leads to lower average rates of money growth and inflation and to greater monetary stability. ${ }^{9}$ The idea is that independence enhances the ability of the central bank to commit to price stability and, hence, to deliver low and stable inflation. Alesina and Summers (1993, Figures $1 \mathrm{a}$ and $\mathrm{b})$ find striking negative relationships among 16 devel oped countries from 1955 to 1988 between an index of the degree of central bank independence and the mean and variance of inflation. Thus, in their context, the measure of central bank independence satisfies one condition needed for a good inflation instrument; it has substantial explanatory power for inflation.

Because of the difficulty of enacting changes in laws, it is plausible that a good deal of the cross-country differences in legal provisions that influence central bank independence can be treated as exogenous. Problems arise, however, if the legal framework changes in response to inflation (although the sign of this interaction is unclear). In addition, exogeneity would be violated if alterations in a country's legal en- 
vironment for monetary policy are correlated with changes in unmeasured institutional features- such as structures that maintain property rights- that influence growth rates. This problem is, however, mitigated by theinclusion of other explanatory variables, notably the index of the rule of law, in theregression framework.

Cukierman (1992, chapter 19) argues that the legal provisions that govern central bank action differ substantially from the way that the banks actually operate. In particular, he distinguishes the legal term of office of the central bank governor from the observed turnover. The latter variable would be more closely related to bank performance (and, hence, to inflation), but cannot be treated as exogenous to growth or omitted third variables. Thus, for the purpose of constructing instruments for inflation, the preferred strategy is to focus on the extent to which inflation can be explained by differences in legal provisions for the central bank.

Table 4 shows an index of central bank independence for 67 countries, based on the information compiled by Cukierman (1992, chapter 19, Appendix A) over time periods that correspond roughly to the four decades from the 1950 s to the 1980 s. The index is an average over thetime periods and for numerous categories of legal provisions contained in the charters of the central banks. (Seethe notes to Table 4.) The details of construction differ somewhat from those used by Cukierman, but the values shown in Table 4 are similar to those reported in his Table 19.3 for the 1980 s.

Table 4 al so contains the average inflation rate from 1960 to 1990 for the 67 countries in my sample that have data on the index of central bank independence. A comparison between the index and the inflation rate reveals a crucial problem; the correlation between the two variables is essentially zero, as in clear from Figure 4. This verdict is also maintained if one looks separately over the three decades from the 1960 s to the 1980s and if one holds constant other possible determinants of inflation. In this broad sample of countries, differences in legal provisions that ought to affect central bank independence have no explanatory power for inflation. ${ }^{10}$ This negative finding is of considerable interest, because it suggests that low inflation cannot be attained merely by instituting legal changes that appear to promote a more independent central bank. However, the result also means that we have to search further for instruments to clarify the relation between growth and inflation. ${ }^{11}$

Lagged inflation. Earlier values of a country's inflation rate have substantial explanatory power for inflation. ${ }^{12}$ Lagged inflation would also be exogenous with respect to innovations in subsequent growth rates. Hence, if lagged inflation is used as an instrument, then the estimated relation between growth and inflation would not tend to reflect the short-run reverse effect of growth on inflation.

One problem, however, is that lagged inflation would reflect persistent characteristics of a country's monetary institutions (such as the extent to which policymakers have credibility), and these characteristics could be correlated with omitted variables that are relevant to growth (such as the extent to which political institutions support the maintenance of property rights). The use of lagged inflation as an instrument would therefore not rule out the problems of interpretation that derive from omitted third variables. However, the inclusion of the other explanatory variables in the regression framework lessens this problem. Another favorable element is that the residuals from the growth equations are not significantly cor related over the time periods.

Column 3 of Table 2 shows the estimated effect of inflation on the growth rate when lagged inflation (over the five years prior to each sample period) is used as an instrument. The estimated coefficient is $-0.020(0.007)$, similar to that found in column 1 when contemporaneous inflation is included as an instrument. Thus, it seems that most of the estimated negative relation between growth and inflation does not represent reverse short-term (negative) effects of growth on inflation.
${ }^{10}$ Cukierman's (1992, chapter 20) results concur with this finding, especially for samples that go beyond a small number of developed countries, the kind of sample used in most of the literature on central bank independence.

${ }^{11}$ Cukierman et al. (1993) use as instruments the tumover rate of bank governors and the average number of changes in bank leadership that occur within six months of a change in government. These measures of actual bank independence have substantial explanatory power for inflation but would not tend to be exogenous with respect to growth.

${ }^{12}$ I have carried out SUR estimation of a panel system with the inflation rate as the dependent variable (for 1965- 75, 1975-85, and 1985-90), where the independent variables are lagged inflation and the other instrumental variables used in Table 2. The estimated coefficient of lagged inflation is 0.74 (0.06). The only other coefficients that reach marginal significance are for $\log (G D P)$, 0.037 (0.019); the blackmarket premium, 0.059 (0.033); the change in the terms of trade, -0.40 (0.22); and the rule-of-law index, -0.009 (0.005). The $R^{2}$ values for the three periods are $0.55,0.24$, and 0.37 . 
Table 4 (continued on following page)

Inflation Rates and Central Bank Independence*

\begin{tabular}{|c|c|c|c|c|c|}
\hline Country & $\begin{array}{c}\text { Index } \\
\text { of Bank } \\
\text { Independence }\end{array}$ & $\begin{array}{c}\text { Inflation } \\
\text { Rate } \\
1960-90\end{array}$ & Country & $\begin{array}{c}\text { Index } \\
\text { of Bank } \\
\text { Independence }\end{array}$ & $\begin{array}{c}\text { Inflation } \\
\text { Rate } \\
1960-90\end{array}$ \\
\hline West Germany & 0.71 & 0.037 & Honduras & 0.44 & 0.058 \\
\hline Sw itzerland & 0.65 & 0.038 & Peru & 0.44 & 0.606 \\
\hline Austria & 0.65 & 0.043 & Chile & 0.43 & 0.416 \\
\hline Egypt & 0.57 & 0.094 & Turkey & 0.42 & 0.235 \\
\hline Denmark & 0.53 & 0.069 & Malta & 0.42 & 0.035 \\
\hline Costa Rica & 0.52 & 0.117 & Iceland & 0.42 & 0.229 \\
\hline Greece & 0.52 & 0.109 & Kenya & 0.40 & 0.082 \\
\hline United States & 0.51 & 0.049 & Lux embourg & 0.40 & 0.044 \\
\hline Ethiopia & 0.50 & 0.058 & Zaire & 0.39 & 0.357 \\
\hline Ireland & 0.50 & 0.083 & Mexico & 0.37 & 0.227 \\
\hline Philippines & 0.49 & 0.107 & Indonesia & 0.36 & 0.366 \\
\hline Bahamas & 0.48 & $0.063 t$ & Botsw ana & 0.36 & 0.076 \\
\hline Tanzania & 0.48 & 0.133 & Ghana & 0.35 & 0.256 \\
\hline Nicaragua & 0.47 & 0.436 & France & 0.34 & 0.064 \\
\hline Israel & 0.47 & 0.350 & Zambia & 0.34 & 0.174 \\
\hline Netherlands & 0.47 & 0.045 & South Africa & 0.33 & 0.099 \\
\hline Canada & 0.47 & 0.054 & Nigeria & 0.33 & 0.125 \\
\hline Venezuela & 0.45 & 0.100 & Malaysia & 0.32 & 0.034 \\
\hline Barbados & 0.44 & 0.075 & Uganda & 0.32 & 0.353 \\
\hline Argentina & 0.44 & 0.891 & Italy & 0.31 & 0.088 \\
\hline
\end{tabular}

* The index of central bank independence is computed from data in Cukierman (1992, chapter 19, Appendix A). The index is a weighted average of the available data from 1950 to 1989 of legal provisions regarding (1) appointment and dismissal of the governor (weight 1/ 6), (2) procedures for the formulation of monetary policy (weight 1/6), (3) objectives of central bank policy (weight 1/6), and (4) limitations on lending by the central bank (weight 1/2). The first category is an unweighted average of

The significant negative influence of inflation on growth still shows up only when the high-inflation observations are included. The results are, however, again consistent with a linear relation and with stability over the time periods. The standard deviation of inflation also remains insignificant if it is added to the regressions (with lagged values of this standard deviation included as instruments).

Prior colonial status. Another possible instrument for inflation comes from the observation that prior colonial status has substantial explanatory power for inflation. Table 5 breaks down averages of inflation rates from 1960 to 1990 by groups of countries classified as non-colonies (defined as those that were independent prior to U.S. independence in 1776) and former colonies of Britain, France, Spain or Portugal, and other countries (in this sample, Australia, Belgium, the N etherlands, N ew Zealand, and the United States).

Table 5 indicates that the average inflation rate for all 117 countries from 1960 to 1990 is 12.6 percent per year. The average for the 30 non-colonies of 8.9 percent is similar to that of 10.4 per- 
Inflation Rates and Central Bank Independence*

\begin{tabular}{|c|c|c|c|c|c|}
\hline Country & $\begin{array}{c}\text { Index } \\
\text { of Bank } \\
\text { Independence }\end{array}$ & $\begin{array}{l}\text { Inflation } \\
\text { Rate } \\
1960-90\end{array}$ & Country & $\begin{array}{c}\text { Index } \\
\text { of Bank } \\
\text { Independence }\end{array}$ & $\begin{array}{c}\text { Inflation } \\
\text { Rate } \\
1960-90\end{array}$ \\
\hline Finland & 0.30 & 0.073 & Panama & 0.23 & 0.033 \\
\hline Sweden & 0.30 & 0.067 & Zimbabwe & 0.22 & 0.074 \\
\hline Singapore & 0.30 & 0.034 & Hungary & 0.21 & 0.047 \\
\hline India & 0.30 & 0.074 & Japan & 0.20 & 0.054 \\
\hline United Kingdom & 0.30 & 0.077 & Pakistan & 0.19 & 0.072 \\
\hline South Korea & 0.29 & 0.113 & Colombia & 0.19 & 0.170 \\
\hline China & 0.29 & 0.039 & Spain & 0.16 & 0.096 \\
\hline Bolivia & 0.29 & 0.466 & Morocco & 0.15 & 0.055 \\
\hline Uruguay & 0.29 & 0.441 & Belgium & 0.13 & 0.048 \\
\hline Brazil & 0.28 & 0.723 & Yugoslavia & 0.12 & 0.395 \\
\hline Australia & 0.27 & 0.067 & Poland & 0.12 & $0.293 \dagger$ \\
\hline Thailand & 0.27 & 0.052 & Norw ay & 0.12 & 0.066 \\
\hline Western Samoa & 0.26 & $0.112 \ddagger$ & & & \\
\hline New Zealand & 0.25 & 0.085 & & & \\
\hline Nepal & 0.23 & 0.084 & & & \\
\hline
\end{tabular}

three underlying variables that involve the governor's term of office and the procedures for appointment and dismissal. The second category is an unweighted average of two variables, one indicating the location of the authority for setting monetary policy and the other specifying methods for resolving conflicts about policy. The third category relates to the prominence attached to price stability in the bank's charter. The fourth category is an unweighted average of four variables: limitations on advances, limitations on securitized lending, an indicator for the location of the authority that prescribes lending terms, and the circle of potential borrowers from the central bank. For each underlying variable, Cukierman defines a scale from 0 to 1 , where 0 indicates least favorable to central bank independence and 1 indicates most favorable. The overall index shown in Table 4 runs correspondingly from 0 to 1 . See Table 1 for a discussion of the inflation data.

$\ddagger 1975-90$

$+1970-90$

cent for the 42 British colonies and 6.6 percent for the 20 French colonies. However, the rates are strikingly higher for the 18 Spanish or Portuguese colonies29.4 percent-and somewhat higher for the 7 other colonies- 16.1 percent.

A key reason for the low average inflation rate for the former French colonies is the participation of most of the sub-Saharan African states in the fixed-exchange rate regime of the CFA Franc. ${ }^{13}$ This type of reasonably exogenous commitment to relatively low inflation is exactly the kind of experiment that provides for a good instrument for inflation.

For many of the former British colonies, a significant element may be their prior experience with British organized currency boards, another system that tends to generate low inflation. ${ }^{14}$ These boards involved, at one time or another before independence, most of the British colonies in Africa, the Caribbean, southeast Asia, and the Middle East.

The high average inflation rate for the 16 former Spanish colonies in the sample does not reflect, per se, their presence in Latin America. For seven Latin American countries that are not former Spanish or Portuguese colonies, ${ }^{15}$ the average inflation rate for $1960-90$ is only 9.0 percent, virtually the same as that for the non-colonies (see Table 5). Also, four former Portuguese colonies in Africa experienced the
${ }^{13}$ For discussions of the CFA Franc zone, see Boughton (forthcoming) and Clement (1994). The zone maintained a fixed exchange rate with the French Franc for 45 years until the de valuation from 50 to $100 \mathrm{CFA}$ Francs per French Franc in J anur ary 1994. At the time of the devaluation, the zone covered 14 African countries grouped around three central banks: the West African Monetary Union of Benin, Burkina Faso, Ivory Coast, Mali, Niger, Senegal, and Togo; a group of central African countries consisting of Cameroon, Central African Republic, Chad, Congo, Equatorial Guinea, and Gabon; and the Comoros. Some original members of the zone left to establish independent currencies- Djibouti in 1949, Guinea in 1958, Mali in 1962 (until it re joined in 1984), Madagascar in 1963, Mauritania in 1973, and the Comoros in 1981 (to set up its own form of CFA franc). Equatorial Guinea, which joined in 1985, is the only member that is not a former colony of France (and not French speaking)

${ }^{14}$ See Schwartz (1993).

${ }^{15}$ The seven in the sample are Barbados, Dominican Republic (attributed to France rather than to Spain; see the notes to Table 5), Guyana, Haiti, Jamaica, Suriname, and Trinidad and Tobago. Five other former British colonies in Latin America that are not in this sample- Bahamas, Belize, Grenada, St. Lucia, and St. Vincent- experienced the relatively low average inflation rate of 6.9 percent from 1970 to 1990. 


\section{Table 5}

\section{Inflation Rates and Prior Colonial Status*}

${ }^{16}$ These four are Angola, Cape Verde, Guinea-Bissau, and Mozambique. Data are unavailable for Cape Verde and Guinea-Bissau in the 1960s (prior to independence). The figures for Angola in the 1980s are rough estimates.

${ }^{17}$ I have carried out SUR estimation of a panel system with the inflation rate as the dependent variable ( for 1965- 75, 1975-85, and 1985-90), where the independent variables are the two colony dummies and the other instrumental variables - mainly lagged variables- used in Table 2. This system excludes lagged inflation (see footnote 12). The estimated coefficient on the Spain-Portugal colonial dummy is $0.14(0.03)$ and that on the dummy for other colonies is $0.11(0.05)$. The $R^{2}$ values are 0.38 for $1965-75,0.14$ for 1975- 85 , and 0.10 for 1985- 90. Thus, inflation is difficult to explain, especially if most contemporaneous variables and lagged inflation are excluded as regressors. Two variables that are sometimes suggested as determinants of inflation - trade openness (measured by lagged ratios of exports and imports to GDP) and country size (measured by $\log$ of population) - are insignificant if added to the system. Years since independence also has no explanatory power for inflation. This result may arise because the former colonies of Spain and Portugal in Latin America became inde pendent at roughly the same time.

${ }^{18}$ See, for example, the results in Barro 1991.

\begin{tabular}{|c|c|c|c|c|c|c|c|}
\hline Period & $\begin{array}{c}\text { All } \\
\text { Countries }\end{array}$ & $\begin{array}{l}\text { Non- } \\
\text { Colony }\end{array}$ & $\begin{array}{l}\text { British } \\
\text { Colony }\end{array}$ & $\begin{array}{l}\text { French } \\
\text { Colony }\end{array}$ & $\begin{array}{c}\text { Spanish or } \\
\text { Portugese } \\
\text { Colony }\end{array}$ & $\begin{array}{l}\text { Other } \\
\text { Colony }\end{array}$ & $\begin{array}{c}\text { Latin America } \\
\text { not Spanish } \\
\text { or Portugese } \\
\text { Colony }\end{array}$ \\
\hline $1960-70$ & $\begin{array}{l}.054 \\
(121)\end{array}$ & $\begin{array}{l}.045 \\
(31)\end{array}$ & $\begin{array}{l}.033 \\
(43)\end{array}$ & $\begin{array}{l}.030 \\
(21)\end{array}$ & $\begin{array}{l}.089 \\
(19)\end{array}$ & $\begin{array}{l}.194 \\
(7)\end{array}$ & $\begin{array}{l}.031 \\
(7)\end{array}$ \\
\hline $1970-80$ & $\begin{array}{l}.131 \\
(131)\end{array}$ & $\begin{array}{l}.110 \\
(32)\end{array}$ & $\begin{array}{l}.120 \\
(50)\end{array}$ & $\begin{array}{l}.093 \\
(20)\end{array}$ & $\begin{array}{l}.218 \\
(21)\end{array}$ & $\begin{array}{l}.147 \\
(8)\end{array}$ & $\begin{array}{l}.109 \\
(11)\end{array}$ \\
\hline $1980-90$ & $\begin{array}{l}.182 \\
(132)\end{array}$ & $\begin{array}{l}.124 \\
(31)\end{array}$ & $\begin{array}{l}.139 \\
(51)\end{array}$ & $\begin{array}{l}.074 \\
(22)\end{array}$ & $\begin{array}{l}.523 \\
(20)\end{array}$ & $\begin{array}{l}.136 \\
(8)\end{array}$ & $\begin{array}{l}.097 \\
(11)\end{array}$ \\
\hline $1960-90$ & $\begin{array}{l}.126 \\
(117)\end{array}$ & $\begin{array}{l}.089 \\
(30)\end{array}$ & $\begin{array}{l}.104 \\
(42)\end{array}$ & $\begin{array}{l}.066 \\
(20)\end{array}$ & $\begin{array}{l}.294 \\
(18)\end{array}$ & $\begin{array}{c}.161 \\
(7)\end{array}$ & $\begin{array}{c}.090 \\
(7)\end{array}$ \\
\hline $\begin{array}{l}\text { * The numbers } \\
\text { Countries tha } \\
\text { Philippines is } \\
\text { attributed to } \\
\text { Poland, Sout } \\
\text { not former S }\end{array}$ & $\begin{array}{l}\text { in parentheses } \\
\text { independent bef } \\
\text { uted to the Unites } \\
\text { e rather than to } S \\
\text { a, and Taiwan. Th } \\
\text { or Portugese col }\end{array}$ & $\begin{array}{l}\text { umbers of } \\
6 \text { are treate } \\
\text { rather than } \\
\text { me countrie } \\
\text { bresent-day }\end{array}$ & $\begin{array}{l}\text { s with availat } \\
n \text {-colonies. } 0 \\
\text {; Rwanda an } \\
\text { ere dominate } \\
n \text { the sample }\end{array}$ & $\begin{array}{l}\text { that fall into } \\
\text {, the colonial } \\
\text { di are attribu } \\
\text { her countires } \\
\text { Kong. The la }\end{array}$ & $\begin{array}{l}\text { tegory. See Table } \\
\text { refers to the most } \\
\text { Belgium rather tha } \\
\text { e periods are treat } \\
\text { nn refers to countr }\end{array}$ & $\begin{array}{l}\text { discussion of } \\
\text { utside power } \\
\text { many; and th } \\
\text { on-colonies. } \\
\text { are located i }\end{array}$ & $\begin{array}{l}\text { flation data. } \\
\text { example, the } \\
\text { minican Republic is } \\
\text { ples are Hungary, } \\
\text { in America but are }\end{array}$ \\
\hline
\end{tabular}

relatively high average inflation rate of around 20 percent. ${ }^{16}$ For Portugal and Spain themselves, the average inflation rate of 10.9 percent for $1960-90$ is well below the rate of 29.4 percent experienced by their former colonies. However, 10.9 percent inflation is substantially higher than that experienced by France (6.4 percent) and the United Kingdom (7.7 percent).

Column 4 of Table 2 shows the estimated effect of inflation on the growth rate of GDP when the instruments exclude contemporaneous or lagged inflation but include indicators of prior colonial status. The two variables used are a dummy for whether the country is a former Spanish or Portuguese colony and a dummy for whether the country is a former colony of a country other than Britain, France, Spain, or Portugal. ${ }^{17}$ The estimated coefficient on the inflation rate is now -0.031 (0.008), somewhat higher in magnitude than that found when contemporaneous or lagged inflation is used as an instrument. The significantly negative relation between growth and inflation again arises only when the high-inflation experiences are included in the sample. The results also continue to be stable over the time periods.

One question about the procedure is whether prior colonial status works in the growth regressions only because it serves as an imperfect proxy for Latin America, a region that is known to have experienced surprisingly weak economic growth. ${ }^{18}$ However, column 5 of Table 2 shows that if a dummy variable for Latin America is included in the system (and the indicators of prior colonial status and the Latin America dummy are used as instruments), then the estimated coefficient of inflation remains negative and significant, -0.025 (0.009). Moreover, the estimated coefficient on the Latin America dummy is only marginally significant, $-0.0060(0.0034)$. The results are basically the same if the Latin America dummy is added to the system from 


\section{Table 6}

\section{Regressions for Investment Ratio*}

\begin{tabular}{|c|c|c|c|}
\hline Variable & 1 & 2 & 3 \\
\hline $\log (G D P)$ & $\begin{array}{r}-.008 \\
(.010)\end{array}$ & $\begin{array}{r}-.011 \\
(.011)\end{array}$ & $\begin{array}{r}-.011 \\
(.010)\end{array}$ \\
\hline Male schooling & $\begin{array}{c}.016 \\
(.011)\end{array}$ & $\begin{array}{l}.010 \\
(.012)\end{array}$ & $\begin{array}{c}.013 \\
(.011)\end{array}$ \\
\hline Female schooling & $\begin{array}{r}-.018 \\
(.012)\end{array}$ & $\begin{array}{r}-.012 \\
(.013)\end{array}$ & $\begin{array}{r}-.016 \\
(.013)\end{array}$ \\
\hline Log(life expectancy) & $\begin{array}{l}.228 \\
(.045)\end{array}$ & $\begin{array}{l}.242 \\
(.047)\end{array}$ & $\begin{array}{l}.231 \\
(.046)\end{array}$ \\
\hline Log(fertility rate) & $\begin{array}{r}-.010 \\
(.018)\end{array}$ & $\begin{array}{r}-.010 \\
(.019)\end{array}$ & $\begin{array}{r}-.013 \\
(.019)\end{array}$ \\
\hline $\begin{array}{l}\text { Government consumption } \\
\text { ratio }\end{array}$ & $\begin{array}{r}-.172 \\
(.083)\end{array}$ & $\begin{array}{c}-.215 \\
(.088)\end{array}$ & $\begin{array}{r}-.220 \\
(.087)\end{array}$ \\
\hline $\begin{array}{l}\text { Public education spending } \\
\text { ratio }\end{array}$ & $\begin{array}{l}.18 \\
(.27)\end{array}$ & $\begin{array}{r}-.06 \\
(.29)\end{array}$ & $\begin{array}{l}.09 \\
(.28)\end{array}$ \\
\hline Black-market premium & $\begin{array}{l}-.017 \\
(.013)\end{array}$ & $\begin{array}{c}.001 \\
(.014)\end{array}$ & $\begin{array}{l}.000 \\
(.015)\end{array}$ \\
\hline Rule-of-law index & $\begin{array}{l}.0150 \\
(.0034)\end{array}$ & $\begin{array}{c}.0151 \\
(.0036)\end{array}$ & $\begin{array}{c}.0146 \\
(.0035)\end{array}$ \\
\hline Terms-of-trade change & $\begin{array}{c}.047 \\
(.062)\end{array}$ & $\begin{array}{l}.060 \\
(.070)\end{array}$ & $\begin{array}{c}.059 \\
(.067)\end{array}$ \\
\hline Democracy index & $\begin{array}{c}.092 \\
(.059)\end{array}$ & $\begin{array}{l}.111 \\
(.066)\end{array}$ & $\begin{array}{l}.103 \\
(.065)\end{array}$ \\
\hline Democracy index squared & $\begin{array}{r}-.096 \\
(.052)\end{array}$ & $\begin{array}{l}-.108 \\
(.059)\end{array}$ & $\begin{array}{r}-.097 \\
(.058)\end{array}$ \\
\hline Inflation rate & $\begin{array}{r}-.001 \\
(.011)\end{array}$ & $\begin{array}{r}-.059 \\
(.017)\end{array}$ & $\begin{array}{r}-.044 \\
(.022)\end{array}$ \\
\hline$R^{2}$ & $.64, .62, .67$ & $.64, .61, .62$ & $.65, .62, .66$ \\
\hline Number of observations & $78,89,84$ & $78,89,84$ & $78,89,84$ \\
\hline
\end{tabular}

* The systems have three equations, where the dependent variables are the ratios of real gross investment to real GDP for 1965- 75, 1975-85, and 1985-90. See the notes to Table 2 for definitions of the variables. Estimation is by instrumental variables. Column 1 includes inflation as an instrument. Column 2 uses inflation over the previous five years as an instrument. Column 3 uses prior colonial status as instruments. See the notes to Table 2 for descriptions of the other instruments.

column 1 of Table 2 , in which contemporaneous inflation is used as an instrument. It therefore appears that much of the estimated effect of a Latin America dummy on growth rates in previous research reflected a proxying of this dummy for high inflation. In particular, the negative effect of inflation on growth does not just reflect the tendency for many high-inflation countries to be in Latin America.

\section{ESTIMATED EFFECTS OF INFLATION ON INVESTMENT}

A likely channel by which inflation decreases growth is through a reduction in the propensity to invest. (This effect is al ready held constant by the presence of the investment ratio in the growth regressions.) I have investigated the determination of the ratio of investment to GDP within a framework that parallels the one 
set out in Table 2. The results are in Table 6.

In the case of the investment ratio, the use of instruments turns out to be crucial for isolating a negative effect of inflation. In column 1 of Table 6 , which uses contemporaneous inflation as an instrument, the estimated coefficient on the inflation rate is virtually zero, $-0.001(0.011)$. In contrast, the result in column 2 with lagged inflation used as an instrument is -0.059 (0.017). Similarly, the result in column 3 with the indicators of prior colonial status used as instruments is -0.044 (0.022). The last two estimates imply that an increase in average inflation by 10 percentage points per year would lower the investment ratio on impact by 0.4 percentage point to 0.6 percentage point.

Even when the instruments are used, the adverse effect of inflation on investment shows up clearly only when the high-inflation observations are included in the sample. This finding accords with the results for growth rates.

growth rate by 0.2 percent to

0.3 percent per year applies on impact in response to a permanent increase in the inflation rate. The growth rate would also decrease for a long time thereafter, but the magnitude of this decrease diminishes toward zero as the economy converges back to its (unchanged) long-run growth rate. Hence, in the very long run, the effect of higher inflation is a path with a permanently lower level of output, not a reduced growth rate. The numerical estimates for the reduced level of output after 30 years take account of these $d y$ namic effects. The calculation depends on the economy's rate of convergence to its long-tem growth rate (assumed, based on the empirical estimates, to be 2 percent to 3 percent per year). Also, the computations unrealistically neglect any responses of the other explanatory variables, such as the human-capital measures and the fertility rate.

\section{CONCLUDING OBSERVATIONS}

A major finding from the empirical analysis is that the estimated effects of inflation on growth and investment are significantly negative when some plausible instruments are used in the statistical procedures. Thus, there is some reason to believe that the relations reflect causation from higher long-term inflation to reduced growth and investment.

It should be stressed that the clear evidence for adverse effects of inflation comes from the experiences of high inflation. The magnitudes of effects are also not that large. For example, an increase in the average inflation rate by 10 percentage points per year is estimated to lower the growth rate of real per capita GDP (on impact) by 0.2 percentage point to 0.3 percentage point per year.

Some people have reacted to these kinds of findings by expressing skepticism about the value of cross-country empirical work. In fact, the wide differences in in- flation experiences offered by the crosssection provide the best opportunity for ascertaining the long-term effects of inflation and other variables on economic performance. If the effects cannot be detected accurately in this kind of sample, then they probably cannot be pinpointed anywhere else. In particular, the usual focus on annual or quarterly time series of 30 to 40 years for one or a few countries is much less promising.

In any event, the apparently small estimated effects of inflation on growth are misleading. Over long periods, these changes in growth rates have dramatic effects on standards of living. For example, a reduction in the growth rate by 0.2 percentage point to 0.3 percentage point per year (produced on impact by 10 percentage points more of average inflation) means that the level of real GDP would be lowered after 30 years by 4 percent to 7 percent. ${ }^{19}$ In mid-1995, the U.S. GDP was over $\$ 7$ trillion; 4 percent to 7 percent of this amount is $\$ 300$ billion to $\$ 500$ billion, more than enough to justify a keen interest in price stability.

\section{REFERENCES}

Alesina, Alberto, and Lawrence H. Summers. "Central Bank Independence and Macroeconomic Performance: Some Comparative Evidence," Journal of Money, Credit and Banking (May 1993), pp. 151- 62.

Bade, Robin, and J. Michael Parkin. "Central Bank Laws and Monetary Policy," unpublished manuscript, University of Western Ontario, (1982).

Barro, Robert J. "Democracy and Growth," Journal of Economic Growth (March 1996), pp. 1- 27.

\footnotetext{
"Economic Growth in a Cross Section of Countries," Quarterly

Journal of Economics (May 1991), pp. 407- 33. and Xavier Sala-i-Martin. Economic Growth. McGraw Hill, 1995.
}

Bollen, Kenneth A. "Political Democracy: Conceptual and Measurement Traps," Studies in Comparative International Development (Spring 1990), pp. 7- 24.

Boughton, James M. "The CFA Franc Zone: Currency Union and Monetary Standard." In Monetary Integration, Anthony Courakis and George Tavlas, eds. Cambridge University Press, forthcoming.

Briault, Clive. "The Costs of Inflation," Bank of England Quarterly Bulletin (February 1995), pp. 33- 45.

Clement, Jean A.P. "Striving for Stability: CFA Franc Realignment,"

Finance \& Development (June 1994), pp. 10- 13. 
Cukierman, Alex. Central Bank Strategy, Credibility, and Independence: Theory and Evidence. MIT Press, 1992.

Pantelis Kalaitzidakis, Lawrence H. Summers, et al. "Central Bank Independence, Growth, Investment, and Real Rates," CamegieRochester Conference Series on Public Policy (Vol. 39, 1993), pp. $95-140$.

Fischer, Stanley. "The Role of Macroeconomic Factors in Growth," Journal of Monetary Economics (Vol. 32, no. 3, 1993), pp. 485- 512

Gastil, Raymond D. and followers. Freedom in the World: Political Rights and Civil Liberties. Greenwood Press, 1982- 83 and other years.

Grier, Kevin B., and Gordon Tullock. "An Empirical Analysis of CrossNational Economic Growth, 1951-80," J ournal of Monetary Economics (Vol. 24, 1989), pp. 259-76.

Grilli, Vittorio; Donato Masciandaro; and Guido Tabellini. "Political and Monetary Institutions and Public Financial Policies in the Industrial Countries," Economic Policy: A European Forum (October 1991), pp. 341- 92.

Knack, Stephen, and Philip Keefer. "Institutions and Economic Performance: Cross-Country Tests Using Alternative Institutional Measures," Economics and Politics (November 1995), pp. 207-27.

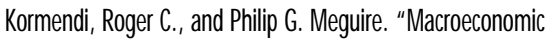
Determinants of Growth: Cross-Country Evidence," J ournal of Monetary Economics (Vol. 16, 1985), pp. 141- 63.

Logue, Dennis $E_{\text {., }}$ and Thomas D. Willett. "A Note on the Relation Between the Rate and Variability of Inflation," Economica (Vol. 43, no. 17, 1976), pp. 151- 58.

Mankiw, N. Gregory; David Romer; and David N. Weil. "A Contribution to the Empirics of Economic Growth," Quarterly Joumal of Economics (May 1992), pp. 407-37.

Okun, Arthur M. "The Mirage of Steady Inflation," Brookings Papers on Economic Activity (Vol. 2, 1971), pp. 485- 98.

Schwartz, Anna J. "Currency Boards: Their Past, Present, and Possible Future Role," Camegie-Rochester Conference Series on Public Policy (Vol. 39, 1993), pp. 147- 88.

Summers, Robert, and Alan Heston. "Penn World Tables, Version 5.5," National Bureau of Economic Research, 1993. 